\title{
Obituary
}

\section{BASIL MITCHELL}

Professor Basil Mitchell, F.B.A., D.D. died on 23 June 2011 at the age of 94. Despite his age, he remained intellectually active long after he retired. He had been Fellow and Tutor in Philosophy at Keble College, Oxford, and his 'swan song' was to organize and chair a conference in 2004 on the work of the theologian Austin Farrer, who had been Warden of the College while he was there. Indeed it was this background as an Oxford philosopher that enabled Basil to fill the Nolloth Chair in the Philosophy of the Christian Religion in Oxford at Oriel College so effectively. He was able to meet Oxford philosophers on their own ground.

Basil was the fourth person to hold the chair, the title of which was originally the Oriel Professorship. He succeeded Ian Ramsey, who left to become Bishop of Durham. Ramsey was a very considerable and influential figure on the national stage, but it is fair to say that his approach to the philosophy of religion was very out of step with the philosophical assumptions of the Oxford of the 1960s, and he made little impact in philosophical circles. He was easily ignored by philosophers such as Professor A. J. Ayer, who was still pursuing his radically empiricist attack on the possibility of metaphysics in general and religion in particular.

In a sense, Ramsey's plight in Oxford was replicated by that of those philosophers scattered in other universities who had a sympathy for religion, or at least a willingness to engage with its philosophical presuppositions. For that reason, he brought them together in a group, which called itself the Christian Philosophers' Group and met for an annual conference in Oxford at Queen's College. The numbers were relatively small, though the group contained some distinguished philosophers. Basil gave the group his full support as Nolloth Professor and attended without fail. Gradually numbers increased, and the group, with Basil, along with John Hick, amongst its prime movers, was able to form one of four national bodies jointly organizing a new society, the European Society for the Philosophy of Religion. One of its first major conferences was held in Oxford in 1978. From that time on, the Christian Philosophers' Group, later to become the British Society for the Philosophy of Religion, held its Oxford conference in alternate years, with the European conference taking place in the intervening ones in various places in northern Europe. Needless to say, Basil was an indefatigable attender, and his quiet influence was invaluable, with both conferences attracting increasing 
numbers. It was appropriate that Basil should be made a Vice-President of the British Society for Philosophy of Religion when it was founded, even though he was already retired. It is a matter of some regret that in recent years British support for the European conference has waned somewhat, although its reach and influence across Europe continue to increase. The 2012 conference will be held in the Netherlands near Utrecht.

Basil was also able to make the philosophy of religion a more significant subject within Oxford and indeed, perhaps as a result, within British universities generally. He was able to provide a bridge between Oxford philosophy and theology, and this took tangible form in the joint Honours degree in Philosophy and Theology that he was able to establish. At the same time the philosophy of religion became a more exciting subject from an intellectual point of view. One major academic argument came from an understanding of the work of the later Wittgenstein. Dewi Phillips, in particular, championed the idea of religion as a 'form of life' with its own internal criteria of meaning. This was an effective rejoinder to the positivism of Ayer, but it seemed to have the result that religion in general, and Christianity in particular, could not be rationally justified from any external standpoint. One was either inside a form of life, or outside it, finding it incomprehensible. There could be no such thing as the justification of religious belief. Reasons could not be given for our most basic religious commitments.

This debate inevitably surfaced frequently in meetings both of the Christian Philosophers' Group and of the European Society. Dewi Phillips defended his views with Welsh passion and humour, while Basil was the epitome of quiet, courteous rationality, exemplifying the very rational sprit he was attempting to defend. One of his most influential books was published in 1973 on this precise issue, and was called The Justification of Religious Belief. In it he developed the idea of a cumulative case argument. In other words, one could use arguments that built up a rational case for religious belief, but one that was not a strict logical proof or an argument from probability. The disagreement with Phillips was of great importance for philosophical notions of religion, and touched on the basic issue of the relation between faith and reason. Indeed Phillips's position was characterized by some as 'Wittgensteinian fideism'. The dispute was a fundamental one, and could easily have developed the kind of rancour that is all too familiar in academic circles. However, discussions over the years in the Christian Philosophers' Group and in wider circles took place in an atmosphere of great cordiality and collegiality. They were intellectually stimulating, and did much to bring the subject to wider attention. For this, Basil through his example is owed a great debt of gratitude.

Basil exhibited all the virtues of his generation of Oxford philosophy. He prized clear thinking, and once remarked sadly of another philosopher that he would never be considered a great philosopher because people could not understand what he was saying. Basil realized that obscurity is all too often mistaken for 
profundity even in theology and some branches of philosophy. On the other side, lucidity can too easily be dismissed as simplification. Yet Basil himself did not succumb to the temptations of some of the Oxford philosophy of his time. He saw that lucidity is a means to an end and not an end in itself. Conceptual clarification is not the sole purpose of philosophy. He wanted philosophical thinking to be of use in the real world. He was very concerned with the role of morality in society and wrote two important books on the topic: Law, Morality and Religion in a Secular Society (1967) and Morality: Religious and Secular (1980), a reworking of his Gifford Lectures. At the same time, he was playing an active role in many Church of England working parties on all the controversial issues that still plague us, such as euthanasia, medical care of the dying, abortion, and homosexuality. He was greatly concerned with religious education and ways in which philosophical views, such as relativism, were leading it astray. He saw the importance of linking science and religion, and played a vital role in establishing the Ian Ramsey Centre in the University of Oxford (significantly named after his predecessor, even though his own philosophical approach to religion was markedly different). The Centre continues to flourish after more than a quarter of a century.

Basil Mitchell presided over a period when the philosophy of religion became much more recognized as an important subject in its own right. The subject flourishes in the United States, and it is eagerly studied in England at 'A' level by many sixth formers. The latter often find the subject so intriguing that they take up philosophy at university. There is an undoubted market for the subject and, when it is taught as an optional course in departments of philosophy, it is widely chosen. The problem is that too often contemporary philosophy departments fail to see its teaching as a priority, and theologians are also sometimes uninterested. Basil Mitchell did much to raise the profile of the subject by his quiet influence. It is to be hoped that his legacy will not be squandered. As it is, his teaching and his books continue to inspire much work in the subject. 